\title{
Influence of the Plastificated Digital PRINTED SheETS ON THE GRAPHIC Products Quality
}

\author{
BABIC, D.; Jurecic, D. \& TOMAS, A.
}

Abstract: The digital printing found the application in printing smaller runs with the aim to get cheaper product. Today's aspects of application and development of the digital printing are directed primarily to the printing quality. Surface finishing of printed products by plastific coating is used on different products (show cards, leaflets, invitation cards ...) or parts of products such as (cover, book jacket, cover for boxes ...) and the finishing processes which are used are cutting, gluing, bending, creasing, back rounding etc. As different from papers printed with the classical printing processes, paper printed with the digital printing techniques and additionally coated with plastic implement the disadvantages as the problem of interactions visible only in the finishing process which results in non acceptance (ugliness) of the final printed products(most often hard cover books). By investigation of the chosen parameters of the digital printing process and finishing of the printed surface by plastic coating, the interventions on the standardized processes are defined.

Key words: digital printing, sheet, coating with plastic, finishing
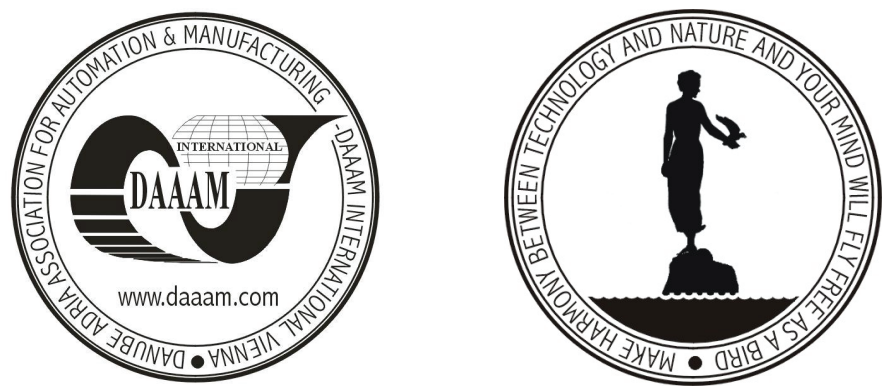

Authors' data: Assoc. Prof. Dr. Babic D.[arko]*, M. Sc. Jurecic D.[enis]*, B.Sc. Tomas A.[nte]**, *Faculty of Graphic Arts, University of Zagreb, Getaldiceva 2, 10000 Zagreb, Croatia, ** Slobodna Dalmacija d.d., Split, Croatia, babic@grf.hr, denis@grf.hr, ante.tomas@slobodnadalmacija.hr

This Publication has to be referred as: Babic, D.; Jurecic, D. \& Tomas, A. (2006). Influence of the Plastificated Digital Printed Sheets on the Graphic Products Quality, Chapter 01 in DAAAM International Scientific Book 2006, B. Katalinic (Ed.), Published by DAAAM International, ISBN 3-901509-47-X, ISSN 1726-9687, Vienna, Austria

DOI: $10.2507 /$ daaam.scibook.2006.01 